Comparative Philosophy Volume 4, No. 1 (2013): 7-41

Open Access / ISSN 2151-6014

www.comparativephilosophy.org

\title{
CONTEMPORARY CONFUCIAN AND ISLAMIC APPROACHES TO DEMOCRACY AND HUMAN RIGHTS
}

\author{
STEPHEN C. ANGLE
}

\begin{abstract}
Both Confucian and Islamic traditions stand in fraught and internally contested relationships with democracy and human rights. It can easily appear that the two traditions are in analogous positions with respect to the values associated with modernity, but a central contention of this essay is that Islam and Confucianism are not analogous in this way. Positions taken by advocates of the traditions are often similar, but the reasoning used to justify these positions differs in crucial ways. Whether one approaches these questions from an intra-traditional, cross-traditional, or multi-traditional perspective, the essay shows that there is great value in getting clear on the ways in which one's textual "canon" may constrain one. In the end, we will see that while there are creative Islamic approaches to taking human rights seriously, the looser constraints under which Confucians operate today may make things easier for Confucian advocates of human rights and democracy.
\end{abstract}

Keywords: Confucianism, Islam, human rights, democracy, tradition, rooted global philosophy, Abu'l-A'la Mawdudi, Abdullahi An-Na'im, Fatima Mernissi, Kang Xiaoguang, Jiang Qing, Tu Wei-ming, Sin-yee Chan, Daniel Bell

Khilafa means "representation." ... What distinguishes Islamic democracy from Western democracy ... is that the latter is based on the concept of popular sovereignty, while the former rests on the principle of popular khilafa. In Western democracy, the people are sovereign; in Islam sovereignty is vested in God and the people are his caliphs or representatives.

$$
\text { -- Abu'l-A'la Mawdudi, Human Rights in Islam }
$$

The inner meaning of [the Confucian concept of] "great unity (da-yi-tong)" is that in actual political society, the king is the representative of public power; the actual political order must be affirmed by the king if it is to be a legitimate political order, because the king has received his mandate from heaven to lead the world, and his leadership

ANGLE, STEPHEN C.: Professor, Department of Philosophy, Wesleyan University, USA. Email: sangle@wesleyan.edu 
has its origins in the sacred legitimacy of heaven.

-- Jiang Qing, Political Confucianism

$* \quad * \quad *$

Is it possible that Islam's message had only a limited and superficial effect on deeply superstitious seventh-century Arabs who failed to integrate its novel approaches to the world and to women? Is it possible that the hijab, the attempt to veil women, that is claimed today to be basic to Muslim identity, is nothing but the expression of the persistence of the pre-Islamic identity ... that Islam was supposed to annihilate?

-- Fatima Mernissi, The Veil and the Male Elite

The conception of gender [implicit in the Analects and Mencius] can neither justify [the various forms of subordination of women the two texts endorsed], nor itself be justified on Confucian grounds. One can discard this early Confucian conception of gender without relinquishing one's commitment to the core doctrines of early Confucianism.

-- Sin-yee Chan, Gender and Relationship Roles in the Analects and the Mencius

In the contemporary world, great non-European spiritual and philosophical traditions like Confucianism and Islam stand in fraught relationships with notions like modernity, the West, democracy, and human rights. Of course, the differences between the Confucian and Islamic traditions are manifold. ${ }^{1}$ In some respects, though, they might still seem to be more similar than I will argue they are. Islamic and Confucian thinkers have been trying for some time to work out the relations between their traditions and ideas like human rights and democracy. Consider the above two pairs of quotations. The contrast between the first pair, which take a quite positive view of the respective traditions, and the second pair, which criticize an aspect of the two traditions (albeit for not being faithful to the tradition's core teachings), suggests that both Islam and Confucianism have complex, internally contested relations to democracy or women's rights. The parallelism between the quotations is meant to raise the possibility that for all this complexity, the two traditions could be in analogous positions with respect to the values associated with modernity.

A central contention of this essay is that Islam and Confucianism are not analogous in this way. Positions taken by advocates of the traditions are often similar, but the reasoning used to justify these positions differs in crucial ways. The differences cluster around the nature of the textual tradition's authority, as it is understood by the thinkers in question, and the relation between that tradition and the justification of contemporary values and institutions. It is important to make these differences explicit because they have significant consequences for all sides in discussions over global political philosophy. When I say "global" philosophy, let me

\footnotetext{
${ }^{1}$ The traditions have developed largely independently from one another, although some excellent recent scholarship has been exploring their interactions in Qing Dynasty China (see, e.g., Zvi Ben Dor Benite 2005 and Murata et. al. 2009), and there have been some tentative steps toward contemporary Confucian - Islamic dialogue (Bakar and Cheng 1997).
} 
be clear from the outset that I do not assume that there is one, privileged philosophical discourse or set of values. Distinct philosophical approaches can be rooted in particular traditions and contexts, and yet simultaneously open - to varying degrees - to stimulus from other values and arguments. Global philosophy is best understood as the totality of all these philosophical practices. Global philosophy is thus includes more than just Western, Islamic, and Confucian discourses. I focus here on Islam and Confucianism because they are two substantial contributors to current discussions, without meaning to suggest that they are representative of all "nonWestern" tradition.

As I use the terms here, both 'Islam' and 'Confucianism' refer to broad and dynamic traditions of reflection and practice. Each tradition is internally diverse and contested, though for the most part the textual canon is shared by all competing approaches. My analysis in the sections that follow is structured by four categories that are meant to highlight key differences in the way a given thinker approaches his or her tradition and its core texts. The categories are:

1. Literalist. The tradition's view on human rights or democracy can be read quite directly off of the authoritative texts; there is no need for extensive hermeneutic intervention.

2. Hermeneutic. Figuring out how the tradition speaks authoritatively to contemporary concerns requires engaging in systematic interpretive practices that themselves have roots in earlier approaches to the textual tradition.

3. Creative transformation. For the tradition's founding texts to have continued relevance today, they must be put into a broad-ranging dialogue with other traditions and values, from which process the tradition and its texts will emerge "transformed," perhaps advocating some ideas that are quite different from those the tradition has historically manifested.

4. Instrumentalist. The tradition's terms and texts can be used by those who are independently committed to the value of human rights or democracy to shape the precise ways in which these modern values are expressed, so as to make human rights or democracy more successfully practiced among those committed to the tradition.

I make comparatively little use of the fourth category, because it does not tend to be an approach engaged in by adherents of the two traditions themselves. I do not claim that these categories exhaust all the ways in which one might relate to a textual tradition, nor that this represents the only possible way to carve up the conceptual space that I am analyzing. In some cases, there may be some fuzziness at the edges of the categories, and a given thinker may engage in more than one mode of justification. Still, I believe that the general shapes of the contrasts that these categories enable me to draw are clear and instructive.

The other category that is central to my analysis has already been alluded to, but it would be well to make more explicit what I mean by philosophical practice that is both rooted and global. This is engaging in philosophy in a way that starts from (is 
rooted in) a particular philosophical tradition, but is open, at least in principle, to the insights and approaches of philosophers and philosophical traditions from around the globe. ${ }^{2}$ It is not premised on the existence of a single set of context-independent truths applicable to everyone on the globe. Rather, it is committed to open-minded and open-ended dialogue. To be sure, if we are to learn from one another, there must turn out to be some concepts or experiences that we have adequately in common. But we need not stipulate in advance what these are. As we will see, a critical issue will be the status of our traditions' textual canons vis-à-vis the ideas of culture and sacredness (one version of which is revelation). Insofar as the sacredness of the Confucian Classics has been lost, global philosophers are then left to draw on the Confucian tradition in much the same way one might draw on the texts of Aristotle or Plato. Does this mean that the only reasons to which a global philosopher can appeal are those that anyone can recognize as reasons? What of the contemporary Islamic thinkers; are they barred from global philosophy if they appeal to reasons grounded in their sacred canon? Not at all. Many Islamic thinkers today are exemplary global philosophers, in that they are open to, and engage with, reasoning from outside their own tradition. ${ }^{3}$ It is quite possible, for instance, to be a devout Muslim and at the same time to feel the force of recent arguments for women's equality or for human rights more generally. ${ }^{4}$ As we will see, this can lead both to constructive theological, philosophical, and interpretive work within the Islamic tradition itself, and to constructive critiques of (for example) the Western human rights tradition. NonMuslim global philosophers should of course be open to such critiques, as well as to the range of insights one may find in the Islamic canon. In a variety of ways, nonMuslims can also take seriously the fact that a given idea or precept is endorsed in the Islamic canon, though non-Muslims will not treat the endorsement in a sacred canon itself as a reason for adopting such an idea. The premise of global philosophy, in short, is not that we must all reason the same, but rather that we often do - at least enough to make real headway in our various philosophical enterprises - when we allow ourselves to be open. At the same time, one of the key issues I will be exploring is the ways in which one's textual canon may constrain one. In the end, we will see that while there are creative Islamic approaches to taking human rights and democracy seriously, the looser constraints under which Confucians operate today may make things easier for Confucian advocates of human rights and democracy.

\footnotetext{
${ }^{2}$ This approach has a similar spirit to that Robert Neville called for in his 1993 Presidential Address to the $8^{\text {th }}$ International Conference on Chinese Philosophy, in which he insisted that Chinese philosophy "constitutes a body of philosophy of worldwide importance"; philosophers everywhere, he added, "need to take account of Chinese philosophy as a living resource for civilized thinking" (Neville 1994).

${ }^{3}$ Note that I am using 'philosopher' here in a broad sense; several of the theorists I will discuss here are not professional philosophers.

${ }^{4}$ Whether someone counts as "devout" is both contestible and admits of degrees, with different communities holding different standards. Some standards may have little to do with belief; Daniel Bell has suggested to me that in many Muslim communities, the ability to read the Qur'an in Arabic may be necessary to count as "devout" (Personal communication).
} 


\section{ISLAM}

There is a large and growing literature on the relations between Islam and notions like democracy and human rights. For my purposes, what we need are representatives of different approaches who can help us to put into relief both the range of substantive claims that are made and the types of justifications that are used. I have chosen three figures, each of whom differs substantially from the others. ${ }^{5}$ There are many other contemporary Islamic writers on whom I could have drawn. My goal has been to select three theorists who are representative of broadly distinctive approaches, whether or not they themselves are currently the most influential practitioners of these approaches. An important limitation of my work here is that I have not endeavored to situate the Islamic or Confucian theorists in their particular historical and microcultural contexts, which would have been necessary to provide a satisfactory explanation of why these individuals came to articulate their relation to their respective traditions in precisely the terms that they have. Such intellectual- and cultural-historical analyses are of course extremely valuable, but fall outside the scope of what I can accomplish here.

The three figures studied in this section share at least two things. ${ }^{6}$ First, they all have a sense that Muslims should be part of the global dialogue over human rights and democracy —none of them rejects human rights or democracy as fundamentally problematic ${ }^{7}$ - even though they disagree on how much change, either in ideals or practice, this will entail for Muslim (or Western) societies. Second, to one degree or another, all reject the idea that what they see as Western-derived formulations of human rights or democracy are in fact universally applicable as they stand. Some would be content with a pluralism in which Islamic human rights conceptions were recognized as equally legitimate with Western alternatives; others hope for dialogue and the possibility of mutual learning. We will see that it is challenging to balance both the tradition's justificatory imperatives and the conceptual or normative upshot of values like human rights.

\subsection{ABU'L-A'LA MAWDUDI}

Sayyid Abu'l-A'la Mawdudi (1903-1979) was the leading theorist of the Islamist movement in Pakistan; his influence was felt throughout the Muslim world. Mawdudi believed that the sorry state of Muslims in his day owed not only to external forces

\footnotetext{
${ }^{5}$ There are many other contemporary Islamic writers on whom I could have drawn. My goal has been to select three theorists who are representative of broadly distinctive approaches, whether or not they themselves are currently the most influential practitioners of these approaches.

${ }^{6} \mathrm{~A}$ third thing that they share is having substantial writings translated into, or written originally in, English, on which my analysis is based.

${ }^{7}$ In contrast to Ayatollah Khomeini, for example, who does reject human rights as alien, despicable values (Mayer 1999, 22 and 27). Another approach I do not consider here is that of secular Muslims who advocate human rights without consideration for how they may or may not mesh with the Islamic canon.
} 
like Western colonialism, but also to the failure of Muslims themselves to follow the teachings of Islam, which he believes can rather straight-forwardly be read off the text of the Islamic canon. ${ }^{8}$ I will thus label him a "literalist." Mawdudi wrote extensively on the meaning of Islam in the contemporary world and on the duties, as he saw them, of committed Muslims. His general approach to issues like human rights and democracy is to argue that Islam has its own distinctive understanding of these ideas, which he aims to show are valuable, coherent, and perhaps superior to Western alternatives. He writes, for instance, "what distinguishes Islamic democracy from Western democracy ... is that the latter is based on the concept of popular sovereignty, while the former rests on the principle of popular khilafa. In Western democracy, the people are sovereign; in Islam sovereignty is vested in God and the people are his caliphs or representatives" (Mawdudi 1980, 10). Khilafa means "representation": Mawdudi explains that by virtue of the powers delegated to us by God, humans are "required to exercise Divine authority" (ibid., 9). Continuing the contrast with Western democracy, Mawdudi says that while in Western democracy, "the people make their own laws, [in Islamic democracy] they follow and obey the laws (shari'a) given by God through his prophet" (ibid., 10).

So far, this may not sound very much like democracy, and indeed, most states that have claimed Islamic legitimacy over the years have been very authoritarian. In Mawdudi's distinctive understanding, though, no individual or dynasty or class can be khilafa: "the authority of khilafa is bestowed on the whole of any community which is ready to fulfill the conditions of representation." To say that authority is bestowed on the whole of a community is to say that each one of its individuals shares in the authority: "Every individual in an Islamic society enjoys the rights and powers of the caliphate of God and in this respect all individuals are equal" (ibid.). In political terms, the opinions of the society's individual members should have decisive influence upon the state's government. Mawdudi states, "Whoever gains their confidence will undertake the duties and obligations of the caliphate on their behalf; and when he loses this confidence he will have to step down" (ibid.). More specifically, Mawdudi sees a government as composed of an amir (leader), who is to be elected by all adult men and women "who subscribe to the fundamentals of the constitution," and a shura (advisory council), which is also elected. A subcommittee of this council, composed of "men learned in Islamic law," is necessary in order to solve interpretive disputes, since "The injunctions of God and His Prophet are to be accepted and obeyed and no legislative body may alter or modify them or make any law contrary to them" (ibid., 13). At the same time, Mawdudi notes "Great scope remains for legislation on questions not covered by specific injunctions of the shari'a" (ibid.). Finally, Mawdudi again emphasizes that "The amir may retain office only so long as he enjoys the confidence of the people and must relinquish it when he

\footnotetext{
${ }^{8}$ By "Islamic canon," I mean the Qu'ran itself, the sunna (deeds of the Prophet), and the sayings (hadith) attributed to the Prophet by his Companions.
} 
loses that confidence. ${ }^{9}$ Every citizen has the right to criticize the amir and his government, and all reasonable means for the ventilation of public opinion must be available." $" 10$

As is probably clear from this brief account, Mawdudi articulates a political framework that aims to build notions of democracy, rights, constitution, political participation, and dissent on Islamic foundations. He sees the various aspects of this framework as realizing the intent of God's revealed will, and at the same time sees the framework as helping to ensure that the letter of God's law is implemented. There may be a tension here between an expansive reading between the lines of scripture, on the one hand, and a literalist commitment to the "law of the shari' $a$," on the other. We will see other thinkers argue for different hermeneutic choices, and will have some opportunity to reflect on the merits of their varying approaches. For the time being, it suffices to note that Mawdudi certainly sees it as essential to his project that his political vision is endorsed by the correct reading of the Islamic canon.

What of the content of Mawdudi's vision? There are tensions here, too. On the one hand, we are told that "every individual in an Islamic society enjoys the rights and powers of the caliphate of God," and that both men and women are entitled to vote for amir. On the other hand, women are constrained in a variety of ways by the content of the shari'a that Mawdudi says must be unbendingly enforced. More generally, Mawdudi's reliance on the "agreement" of individuals-which taken together constitute the "confidence" of the people-sits awkwardly with his requirement that "men learned in Islamic law" (as well as, in a later paragraph, the judiciary) have ultimate authority to interpret God's revealed will, which after all is the basis for the authority of the people as representatives of God. If the people endorse a leader explicitly committed to policies that rest on interpretations of scripture that the (conservative, let us imagine) learned men oppose, whose authority wins? Unless it is typically the people's, it is hard to see the justification for thinking of Mawdudi's framework as democratic. ${ }^{11}$

\footnotetext{
${ }^{9}$ See also (Mawdudi 1960, 175) in which he makes explicit that when a leader fails to act in a proper Muslim manner, "It would become permissible for Muslims to strive to change the order of things." This is strikingly similar to the Confucian doctrine of justified rebellion, on which see Mencius 1B:8. In fact several aspects of Mawdudi's account have strong Confucian correlates; see also the role that "tian" (or heaven) plays in legitimating a king's rule, as expressed through the approval of the people, in Mencius 5A:5.

${ }^{10} \mathrm{Ibid}$. On the other hand, in earlier writings, Mawdudi put more stress on obedience, writing that "It is not permitted that one should, by unnecessarily raising issues with [leaders] and creating an atmosphere of strife and conflict, disturb the life of the community" (Mawdudi 1960, 173-4). One analyst sees a modification in Mawdudi's theoretical emphasis stemming from his involvement in practical politics and his influence on policy; see Nasr 1996, 93.

${ }^{11}$ A more detailed analysis of Mawdudi's vision of democracy than I have room for here would pursue this question in the context of practices of judicial review in the U.S. and elsewhere. One difference we can note here stems from Mawdudi's distinction between popular sovereignty (in the West) and God's sovereignty. In the U.S. the people have the final say, since they can amend the Constitution; the Mawdudi's framework, the interpretation of scripture by the learned men is final.
} 
Turn now to Mawdudi's discussion of human rights. Human rights in Islam, he says, are "those rights granted by God" (ibid., 15). As he sees it, human rights have only comparatively recently been recognized and endorsed within the European tradition - he ridicules the idea that they can be traced back to the Magna Cartawhile human rights in the Islamic sense were firmly ensconced in the Qur'an in the seventh century. Mawdudi lists a series of rights, explaining how each is found in the Islamic canon; these include the rights to life, to a basic standard of life, to freedom, to justice, to the protection of honor, to protest against tyranny, and others.

None of the passages that Mawdudi cites contain the word "right."12 Like other great normative traditions, that is, Islam's founding texts were not explicitly couched in terms of rights, but rather in terms of commands, duties, visions of perfection, and so on. Unlike some subsequent thinkers we will examine, Mawdudi glosses over this fact, treating it as uncontroversial that human rights have been part of Islam from the beginning. He treats injunctions against killing as signifying the right to life and praise for saving lives as signifying the "right to the safety of life" (ibid., 18). From the statement in the Qur'an that "God does not love evil talk in public unless it is by someone who has been injured thereby," he concludes that "God strongly disapproves of abusive language or strong words of condemnation, but that the person who has been the victim of injustice or tyranny has the right to protest strongly against the injury that has been done to him," which he codifies as the right to protest against tyranny (ibid., 28).

Part of the significance of the questions I have raised about Mawdudi's assertion that an Islamic version of human rights can be found in the Qur'an lie in helping us to see what he means by "human right." It may be that Mawdudi really just means "human values," or something close to this: Islamic human rights are duties and ideals as much as rights. On the other hand, if we take the locution "human right" more strictly, we can see a recurrence of one of the tensions I identified above, namely between a literalist and expansive reading of the canon. Is God's willingness to countenance the abusive speech of one who has been injured really the same as a general right to criticize tyranny? What if, by some chance, I have not been injured by our local tyrant; can I nonetheless criticize him?

Another good example of the difficulty of basing a doctrine of human rights on a literalist reading of the canon can be seen in Mawdudi's treatment of freedom and slavery. He writes: "Islam has categorically forbidden the primitive practice of capturing a free man to make him a slave or to sell him into slavery" [Ibid, 19]; Mawdudi cites a hadith to support this. He argues that the historical effects of this principle were tremendously beneficial, largely resolving the issue of slavery in Arabia in under forty years, and that those slaves who remained-all prisoners of war captured on the battlefield-were treated much more humanely than slaves or prisoners of war have been treated in Europe or the United States. Suppose we accept

\footnotetext{
${ }^{12}$ There is one possible exception; see [Ibid, 18], citing Qur'an 51:19 (misidentified in the text as 51:12). Translators disagree on whether to read "rights" in the passage; compare ("Ali 1999, 1358) and (Arberry 1955, 237).
} 
all this as historical fact. Notice, though, that Mawdudi has not said that individuals have a right to be free from slavery. It is apparently no violation of Islamic human rights for people to be slaves, so long as they are enslaved in the right way (viz., captured in war) and treated reasonably well. The "Individual's Right to Freedom" is thus curiously qualified and hard to state as a general principle. Of course, we can see why the policy endorsed in the Islamic canon might have been reasonable at the time; it may well have led in practice to better fates for slaves in the seventh- and eighthcentury Middle East than any alternative policy. But it is hard to see why people today should endorse Mawdudi's principle.

I have endeavored to show ways in which both Mawdudi's discussion of democracy, and his account of human rights, are seriously constrained by his literalist reading of the Islamic canon. Whether this is a problem depends on two things. First, is one gripped by the value of human rights norms, as those are broadly understood in international documents? If so, then - as I have suggested in the case of slavery, for example-Mawdudi's project will seem flawed. Second, how do we resolve, both in principle and in practice, the tensions in his understanding of democracy between individual political participation and elite interpretation of the canon? In the end, does it make sense to call "democratic" a structure in which God is sovereign and a small number of individuals have the power to put this sovereignty into practice? My goal here is not to prejudge the answers to these questions, but simply to suggest ways in which different approaches to justification lead to different sorts of questions. Let us now turn, therefore, to a second approach, the hermeneutic.

\subsection{ABDULLAHI AN-NA'IM}

An-Na'im (1946- ) is a Sudanese human rights activist and legal scholar who has taught in the United States since 1995. He is best-known for his development of the ideas of his Sudanese mentor, Mahmoud Mohamed Taha, which provide a sophisticated "evolutionary" interpretation of the Islamic canon that is largely compatible with international human rights norms. An-Na'im differs from Sayyid Mawdudi in two fundamental ways. First, he is engaged with, and sees the point of, non-Islamic discussions of human rights. Rather than just reading off whatever "human rights" he finds pre-packaged in scripture, as Mawdudi does, An-Na'im recognizes much of the weight of Western insights into human rights and critiques of the failings both of Western and non-Western societies to adequately protect these rights. Second, An-Na'im's approach to the interpretation of the canon is both more traditional, and more radical, than Mawdudi. As I will explain, with the help of various traditional hermeneutic tools An-Na'im develops an interpretive methodology that enables some quite radical conclusions. In contrast to Mawdudi's "literalist" approach, I will label An-Na'im's strategy "hermeneutic."

At the core of An-Na'im's interpretation is the idea of naskh, or abrogation. Abrogation means that one revelation by God can replace another. According to the tradition, naskh applies both at a macro level (as when Islam superceded Christianity, just as Christianity had superceded Judaism) and at a micro level (whenever one 
revelation in the Qur'an is taken to abrogate another, contradictory revelation). It is not just that such a doctrine seems needed to make sense of the conflicts among divine revelations; in fact the Qur'an contains a number of specific references to progression in revelation (Brown 1998, 52). The second key element to the Taha/AnNa'im thesis is that God's will was revealed to Mohamed in two stages, first in Mecca and subsequently in Medina. This is broadly accepted in the tradition. In keeping with the idea of progressive revelation, though, traditional accounts have seen Meccan revelation being superceded by the subsequent revelation in Medina, whenever there are conflicts. For anyone moved by arguments in favor of women's rights, civil liberties, or other human rights, however, the abrogation of Meccan revelation in favor of Medinan teachings is a problem. An-Na'im asserts that where the Meccan message "emphasized the fundamental values of justice and the equality and inherent dignity of all human beings," in Medina the message shifted, becoming:

Specifically addressed to the Muslims as a community of believers who were authorized by the Qur'an to use force, first in self-defense and in retaliation for the injustice done to them by the unbelievers, and subsequently in propagating Islam and spreading the domain of the Muslim state. (An-Na'im 1990, 54).

For the most part, these more specific teachings contain the passages of scripture which human rights advocates now tend to view as problematic; for instance, "all the verses...that constituted the basis of discrimination against women and non-Muslims were of the Medina and not Mecca stage" (ibid.).

Traditional interpretations, as I have said, view the Medina stage as abrogating the Mecca revelations. And An-Na'im agrees with this, up to a point. He argues that since the Qur'an represents the final revelation - according to Islamic teaching — God had to put all cards into play, so to speak, even if human society was not yet ready for them. Meccan revelation represents an ideal that humans in the seventh century were clearly not ready to realize. Thus it was appropriate for these verses to be superceded by more practical, harsher doctrines. But this abrogation cannot have been intended to be permanent, since then what would have been the point of the earlier revelation? Following Taha, An-Na'im proposes that since human society has now reached a stage at which realization of broad ideals of human justice and equality is possible, it is time for Muslims to return to what Taha calls "the second message of Islam," namely the revelations at Mecca. ${ }^{13}$

A specific example will be helpful. An-Na'im points out that while Shari'a (that is, historical Islamic law) sought to limit slavery and encourage emancipation, slavery is nonetheless lawful under Shari'a to the present day (ibid., 173). This statement is consistent with the odd "human right not to be enslaved" that, as we have already seen, Mawdudi reads off of the canon. An-Na'im's response to this endorsement of slavery is three-fold. First, he argues that several attempts to maintain that the Qur'an can in fact be read as prohibiting slavery "are guilty of selective citation of Shari'a

\footnotetext{
${ }^{13}$ In addition to An-Na'im 1990, see Taha 1987, which is An-Na'im's translation of Taha's most important book.
} 
sources leading to serious distortion and confusion" (ibid.). A centerpiece of AnNa'im's approach is his thorough hermeneutic method and opposition to ad hoc efforts to "fix" Shari'a. Second, he argues that despite the refreshing frankness of interpreters like Mawdudi, ${ }^{14}$ powerful independent arguments lead us to a transcultural justification for basic human rights, including the prohibition of slavery. An-Na'im emphasizes that he does not accept international human rights norms simply because they are enshrined in international agreements; to the contrary, he says "the rights are recognized by the documents because they are universal human rights" (ibid., 166). Finally, An-Na'im invokes Taha's "evolutionary approach"though without explicitly arguing that problematic verses are all from the Medina period - to "conclude that though Shari'a implemented the transitional legislative intent to permit slavery, subject to certain limitations and safeguards, modern Islamic law should now implement the fundamental Islamic legislative intent to prohibit slavery forever" (ibid., 175). ${ }^{15}$

I believe that the power of An-Na'im's approach should be apparent. Even though it offers dramatically different conclusions from earlier Islamic jurisprudence, it is put forward as an extension of these traditional methods, rather than their rejection. Viewed through Taha's and An-Na'im's lens, Islam becomes a beacon for human rights - an ideal calling upon all believers to work for the realization of universal human rights. In addition, the human rights recognized through this approach are substantially the same as those derived from other, internationally prominent arguments and agreements.

An-Na'im has many supporters and fellow-travelers - the latter being those who do not endorse his specific approach, but nonetheless share his goal of a robust, modern, hermeneutically rigorous Islamic human rights regime. ${ }^{16} \mathrm{He}$ also has many critics, who accuse him, on the one hand, of being overly concerned with jurisprudential minutiae or else too literalist; and on the other hand, of being overly radical, even heretical. This is not the place to enter into such debates. My goal instead has been to present a clear example of a hermeneutic approach to Islam and human rights - an approach that seeks change and serious engagement with human rights, even while it maintains contact with the tradition and with believers. It is now time to consider an even more radical approach, and I will return at the end of the essay to broader reflection on strengths and weaknesses of An-Na'im's hermeneutics.

\footnotetext{
${ }^{14}$ An-Na'im discusses the views of Sultanhussein Tabandeh (Tabandeh 1970), not Mawdudi, but on this point they are very similar.

${ }^{15}$ We should be skeptical if in every case, An-Na'im claims that Medinan verses neatly coincide with his contemporary, transcultural justification for human rights - and, for that matter, with the letter of international human rights agreements. In fact, An-Na'im recognizes discrepancies and seeks to deal with them in other terms. For instance, he argues that the "purely religious rationalizations" found in the canon for various punishments for criminal offences "provide insufficient justification for including these offenses and their punishments in the criminal law of a modern nation-state" (AnNa'im 1990, 114-15). The details of his argument cannot occupy us here, but it is primarily based on practical considerations, especially in states with non-Muslim citizens.

${ }^{16}$ Examples might include Rahman 1982, Moosa 2001 and arguably Arkoun 1993.
} 


\subsection{FATIMA MERNISSI}

Fatima Mernissi (1940- ) is a Moroccan sociologist, feminist, and gifted author of books including The Veil and the Male Elite, Behind the Veil, and Islam and Democracy: Fear of the Modern World. There certainly is a hermeneutic aspect to her work, but in various ways she pushes further than An-Na'im, questioning the status of hadith in general, and wondering whether Islam only superficially penetrated the thinking of $7^{\text {th }}$ century Arabs. Mernissi is influenced by the Malikite school of Islamic jurisprudence, which puts considerable weight on reason and on questioning, but her conclusions are more radical than those of the received Malikite tradition. Basing herself ultimately on her faith in God and in what she understands to be Mohammed's fundamental vision, Mernissi calls for a transformation of Islam around the idea of women's rights. ${ }^{17}$

A major part of Mernissi's book The Veil and the Male Elite-subtitled A Feminist Interpretation of Women's Rights in Islam-revolves around the hadith "Those who entrust their affairs to a woman will never know prosperity" (Mernissi 1991, 1). Hadith are accounts of what the prophet Mohammed said and did, as remembered and recorded by his Companions. Hadith thus make up an important part of the Islamic canon, and are generally taken to be as authoritative as the revealed Qur'an itself, inasmuch as the hadith provide context for interpreting the Qur'an. The saying on which Mernissi focuses is thus a major roadblock to female leadership and political rights.

Much of what Mernissi says in response would count as a "hermeneutic" approach. In fact she dwells for some time on the traditional hermeneutic response to a given hadith, which involves exploring the early commentaries and collections, understanding the historical context in which the hadith was uttered and recorded in as much detail as possible, and then evaluating both the reliability of the Companion who "remembered" the hadith, and the authority of the hadith more generally. In all of this, Mernissi is guided by the Malikite dictum of, as she puts it, "question[ing] everything and everybody, especially the fuqaha [religious scholars] and imams" (ibid., 76). Her investigations lead Mernissi to be deeply suspicious of Abu Bakra, the Companion to whom the hadith in question is attributed. ${ }^{18}$ Not only does the historical context show that Abu Bakra may well have had an ulterior motive in "remembering" the saying, but he should also be disqualified from transmitting hadith on moral grounds, since he apparently was convicted of false testimony in a separate matter (ibid., 60).

All of this falls within at least the Malikite school's understanding of traditional hermeneutics, and is not dramatically different from the approach any of the schools would advocate. Mernissi is really stalking larger game than just Abu Bakra and this single hadith, however. She goes on to apply similar treatment, albeit much more

\footnotetext{
${ }^{17}$ Mernissi is far from being the only scholar working on a feminist transformation of the Islamic tradition; another well-known example is Amina Wadud; see Wadud 1999.

${ }^{18}$ Abu Bakra is a relatively obscure Companion, not to be confused with Abu Bakr, the Prophet's father-in-law.
} 
briefly, to other hadith that undermine the status of women, and suggests that what we really see at work is a pre-existing misogynistic trend in society that quickly reasserted itself among religious scholars despite the fundamentally egalitarian teachings of Mohammed himself. She asks:

Is it possible that Islam's message had only a limited and superficial effect on deeply superstitious seventh-century Arabs who failed to integrate its novel approaches to the world and to women? Is it possible that the hajib, the attempt to veil women, that is claimed today to be basic to Muslim identity, is nothing but the expression of the persistence of the pre-Islamic mentality, the jahiliya mentality that Islam was supposed to annihilate?" (ibid., 81).

Later in her book, Mernissi argues that the philosophy of veiling women ran explicitly counter to "Mohammed's dream of a society in which women could move freely around the city because social control would be the Muslim faith that disciplines desire" (ibid., 187). She explains the historical circumstances in which Muslim leaders, and especially the second Caliph 'Umar, chose to impose the hijab instead of insisting on changed attitudes and internal control. The result is "a very grave compromise with the Muslim idea of a reasoning human being who exercises self-control" which would "overshadow Islam's dimension as a civilization, as a body of thought on the individual and his/her role in society" (ibid., 188).

Mernissi offers comparatively little detail of her positive account of Islam, though its dimensions should be clear from the preceding paragraph. Equally clear is that "disinter[ring] our true tradition from the centuries of oblivion that have managed to obscure it" (ibid., 77) is a vast, open-ended task. It is with this in mind that I would label Mernissi's approach to human rights and Islam one of "transformation," a transformation that seems inevitably to be linked to her engagement with other, contemporary value systems, in addition to her efforts at reconstructing the true purport of God's revelation to Mohammed. Indeed, her talk of "Mohammed's dream" tends to put Mohammed's own agency in the foreground, rather than viewing him simply as a vessel for transmitting God's will. Perhaps Mohammed's dream can be better realized in certain ways that depart from the details of revelation? If so, then Mernissi edges toward what I will call below "creative transformation." Certainly Mernissi is not alone in advocating such an approach, but the very possibility is deeply worrying to other Muslims, even fairly liberal ones: is she contesting among interpretations of revelation, or contesting revelation itself? ${ }^{19}$

Mernissi, An-Na'im, and Mawdudi certainly do not exhaust the possible ways in which Muslims can seek to reconcile, or otherwise promote dialogue between, Islam and human rights or democracy. ${ }^{20}$ The approaches they represent are adequate to set

\footnotetext{
${ }^{19}$ See Kurzman 1998, 17. Another example of someone pushing toward creative transformation is Othman 1999.

${ }^{20}$ In addition to individuals already referred to in previous notes, Tariq Ramadan has been developing a distinctive view on these matters, constructing a view of human rights and democracy (among other things) on the core values he finds in the Islamic canon. See Ramadan 2001 and Ramadan 2004.
} 
up comparisons and contrasts with contemporary Confucian positions, though, which is the main object of the present essay. As we work through the details of Confucian literalist, hermeneutic, and transformative approaches, it will become clear that the relation in which a tradition stands to its core texts has enormous implications for the flexibility with which members of these traditions can approach new, and potentially attractive, values and institutions like democracy and human rights.

\section{CONFUCIANISM}

Confucianism and human rights; Confucianism and democracy; Confucianism as political philosophy: these topics are not new, having been discussed from various perspectives throughout the last century, but they have received renewed attention in the last decade. Mirroring my approach to Islam in the previous section, here I will focus on questions related to the justification of claims about the relation between Confucianism and human rights or democracy. ${ }^{21}$ Furthering the premise of this essay - namely, that the approaches of Muslims and Confucians toward values like human rights can seem analogous, even though they are not-I will choose Confucian voices who share the same mixed attitudes toward human rights as my three Islamic exemplars. These Confucians are all committed, to one degree or another, to the importance of human rights and democracy, but none of them believes that these values can (or should) be successfully embraced by the Chinese without significant changes. $^{22,23}$

The reasoning we see from my main examples comes in several forms. For some, interpretive reliance on the Confucian canon is essential. All of them advert to one or another kind of culturalist or nationalist argument, though we will see that these are not all created equal. For some, explicitly political considerations are important, and we also see an instrumentalist justification (i.e., unless Confucian considerations are taken into account, implementation of human rights will not succeed in China). Finally, all my examples also rely, to one degree or another, on reasoning they could expect non-Confucians to find accessible and perhaps persuasive, which I call global philosophical reasoning. Once we have worked through all these kinds of justifications for taking Confucianism seriously, we will see that while different groups might appropriately find some of the reasons compelling, the structure of

\footnotetext{
${ }^{21}$ One difference from the previous section is linguistic: the writings of Kang Xiaoguang and Jiang Qing (as well as a few other authors I cite) are available only in Chinese. All translations from these texts are my own. For a more extensive treatment of contemporary Confucian political philosophy, see Angle 2012.

${ }^{22}$ Just as some Muslims completely reject talk of human rights or democracy, it is certainly possible to find Chinese voices who reject both, though the reasons tend to be Marxist (based on the "bourgeois" nature of human rights and/or representative democracy) rather than Confucian, and are considerably less common today than in past decades. Another perspective I do not consider here is the argument that Confucianism is simply incompatible with human rights or democracy. See Ci 1999 for an example.

${ }^{23}$ Like Islam, Confucianism is not confined to a single modern nation. Many of the issues discussed in this section apply, with some modifications, to people in other countries - and particularly to Korea.
} 
these compelling justifications are quite different from those of the Islamic thinkers considered above.

\subsection{KANG XIAOGUANG}

Born in 1963 and initially trained in physics, Kang Xiaoguang is a social scientist and public intellectual who has become persuaded that China must replace its communist ideology with a soft authoritarianism based on Confucianism. ${ }^{24}$ His writings are passionate and incisive, sparkling with insight and argumentation that draw on many sources. Kang's main Confucian sources include the classical canon, some Han dynasty developments, and the turn-of-the-twentieth-century Confucian reformer Kang Youwei, who argued that Confucianism had to be installed as a state religion if China was to rise again. ${ }^{25}$ I will show that Kang can appear to be a literalist like Mawdudi, finding rights in the Confucian tradition and arguing that Chinese people should embrace, or at any rate be content with, the limited scope of rights endorsed in this tradition. To some degree Kang evinces a more full-blooded commitment to open-minded political theorizing than did Mawdudi, as when Kang discusses some limited means of institutionalizing a "right to political participation" that finds only the faintest echo in the Confucian tradition. I will maintain, though, that the biggest difference between Kang and Mawdudi lies not in either of their specific proposals, but in the intellectual and cultural context in which they make their arguments. At the core of Kang's proposals is the effort to revive Confucianism and, furthermore, to have it established as a state religion in China. Mawdudi, to be sure, was also a kind of revivalist, but in a context of already existing, widespread, and explicit commitment to Islam. Kang's revivalism, in contrast, is widely viewed as quixotic at best.

A telling example of the justificatory role Confucian texts play in Kang's thought comes when Kang considers how a modern authoritarian state in China should deal with the question of leadership succession. After a brief contrast between ancient Chinese practice (heredity, palace coup, and violent revolt) and the methods advocated in Confucian classics, Kang endorses the latter as appropriate to today's China. Specifically, he writes:

Today, when we think about the principles of succession for the highest leaders, pride of place ought to go to recommendation by the community of Confucians (ru-shi), after which comes abdication, after which comes revolution. In actuality, recommendation by the community of Confucians is a form of elite democracy. Abdication in fact comes down to recommending the worthy. Revolution is the worst option, but we cannot deny its legitimacy, which is just to say that we must acknowledge the right of the masses to overthrow a tyrannical government. (Kang 2005, xxxiii)

\footnotetext{
${ }^{24}$ Ownby 2009 is a useful study of some of Kang's ideas and goals.

${ }^{25}$ Kang Youwei also relied heavily on an interpretation of the Classics that grew out of the Gongyang hermeneutical tradition. While Kang Xiaoguang does not emphasize this point in his arguments for Confucianism, we will soon see that it is a central point for Jiang Qing.
} 
Strikingly, Kang then goes on to argue that this Confucian practice of succession is already being practiced in contemporary China. He suggests that the transitions from one CCP leader to another have been "abdications," and furthermore that - just as we read in Mencius - only abdications that are accepted by the masses are truly legitimate. ${ }^{26}$ Mao's abdication in favor of Hua Guofeng failed because the masses did not support him. Deng Xiaoping's abdication eventually succeeded (with Jiang Zeming), despite the masses' rejection of Hu Yaobang and Zhao Ziyang (ibid.).

The difficulties with Kang's position are numerous. At the surface-level, it seems a grotesque distortion of recent history to say that the "masses" were an obstacle to $\mathrm{Hu}$ Yaobang's or Zhao Ziyang's rising to the position of central leader. These were matters of policy disagreements, jealousies, and simple power disputes among a small group of elite Party leaders. A deeper problem has to do with whether, on either Kang's own view or on the classical Confucian view he is invoking, the masses ( $\mathrm{min}$ ) can accurately be seen as judging, choosing, accepting, or in some other way exercising agency. Though I cannot make the whole argument here, I believe the right reading of Mencius, at least, is to see the masses as passive and reactive. Their acquiescence or resistance to a leader is a reliable index of whether the leader rules well, but does not represent any kind of judgment or considered endorsement of the ruler. Furthermore, and pace Kang's reading, the masses have no "right" to rebel, even though they will do so if ruled badly (Angle 2002, 124-5). (That Kang implies the masses have a "right" to rebel, but not to any other form of political participation, is an issue I will address in a moment.)

I have run through these two types of objections to Kang rather quickly because my focus here is on a still-deeper issue, namely: suppose Kang were right about the facts of mass support/rejection, and about his reading of Mencius. Why is this relevant to contemporary political legitimacy? Isn't he trying to justify a flawed current practice in terms of an ancient, but now irrelevant, ideal? Another way of putting the point is this: for Mawdudi, An-Na'im, and other Islamic theorists, the answer to why one should care about justifying political arrangements in terms of the Islamic canon is simple. These are the words of the Prophet, revealed truth to which all should subscribe. What is Kang's answer to why one should justify political arrangements in terms of the Confucian canon?

Kang's answer has several, mutually reinforcing aspects, but none of them advert to the simple truth of Confucian claims. I grant that, in part because of the strengths he sees in (Western-style) religion, his interpretation of traditional Confucianism and his proposals for manufacturing a Confucian state religion put a distinctive emphasis on Confucian "believers." He criticizes those who treat Confucianism merely as an academic theory, characterizes traditional bureaucrats as "priests (jiao-shi)," and views the premodern masses as "believers (xin-tu)" (ibid., xxx; 184). But these views all focus on behavior and its motivations, not on whether the underlying teachings are true. And all of Kang's more explicit justifications for the adoption of Confucianism

\footnotetext{
${ }^{26}$ See Mencius 5A:5, as well as my discussion below.
} 
are highly extrinsic. In brief, Kang argues along the following two lines. First, authoritarianism is a better choice for China today than is democracy, but Marxism no longer provides a credible legitimation for China's economic and social structures. In addition, contemporary Chinese society is rife with severe injustice as capitalists and government bureaucrats conspire to exploit the peasants and workers. In other words, contemporary Chinese authoritarianism fails on internal legitimacy grounds and on moral grounds. Confucianism, in contrast, fits well with many aspects of contemporary authoritarianism, but has a robust theory of legitimacy and powerful teachings regarding justice and compassion. It is thus the best choice for Chinese today (ibid., xliii; 139). Kang's second approach is to argue that Confucianism is intimately linked to Chinese culture, and that the preservation of Chinese culture is necessary if China is to flourish - or perhaps even survive - in an era of global competition among civilizations (ibid., 182).

I will consider each of these two lines of thought in turn, beginning with the argument that Confucianism is the best choice for contemporary China. As throughout this essay, I will keep my focus on how Kang seeks to justify his claims. For instance, when he says that (unlike contemporary Marxism) Confucianism can meet its own standards of legitimacy, Kang adverts to Confucian texts to spell out the standards in question. He argues that a polity based on "benevolent government" will be legitimate in three senses - popular, spiritual, and cultural-since one can find statements referring to endorsement by the masses, by "heaven," and by tradition in the Confucian classics (ibid., 139). ${ }^{27}$ But this is asking whether an ideal Confucianism meets its ideals, rather than asking whether Confucianism-in-practice can live up to its ideals. The issue with Marxism in China today is not (mainly) a theoretical failure, but a disconnection between the increasingly market-driven society and Marxism's egalitarian ideals. In this regard, it is striking that Kang recognizes that Confucianism has shortcomings when it comes to the actual expression of popular legitimacy. He writes: "How do politics express the mass will (min-yi)? This is a challenge that contemporary Confucianism faces, and an area in which Confucianism's reserves of knowledge are not substantial. We must seek to learn from contemporary political theory and political practice" (ibid., xxxv). He suggests that free mass media, institutions of political consultation, and corporatism offer adequate answers to guaranteeing the "masses' right to political participation" (ibid., xxxvii). Kang then offers an astute analysis of the potential weaknesses of these solutions, but contends that the right to free association and full-fledged democracy within each "functional constituency" will be adequate to fend off abuses of the system by government and capitalist interests.

My purpose here is not to assess the case Kang has made for a form of consultative, corporatist politics. ${ }^{28}$ Rather, let us ask what the role of Confucianism is in all this? Does Confucianism ground his talk of a "right to political participation,"

\footnotetext{
${ }^{27}$ Kang's analysis of legitimacy into these three dimensions is drawn from the more detailed argument of Jiang Qing, whom Kang cites approvingly (and whom I will discuss in my next section).

${ }^{28}$ I engage with related proposals offered by recent theorists in the name of reforming democratic centralism in Angle 2005a and Angle 2005b.
} 
on the basis of which he proposes these institutional innovations? Are consultation and corporatism more Confucian than direct elections and universal suffrage would be? Remember that in Kang's discussion of the succession issue, he was only able to find a vague role for popular acceptance of a new leader — which I further argued was passive and reactive, rather than expressing positive agency and judgment-rather than any full-fledged notion of political participation. It is true that the Analects envisions an important if diffuse political role for all people with enough education and agency to qualify as "individuals (ren)," but the masses are merely led. ${ }^{29}$ In other words, I would argue that Kang's thoughtful reasoning about realizing the right to political participation is grounded (perhaps unbeknownst to him) not in Confucianism, but in other aspects of global philosophy on which he is building. An important consequence of this is that as we push towards the values or ideals grounding the rights Kang articulates, we can question whether these rights can stand alone, or whether recognition of rights to free press and free association, for instance, may also require (for either conceptual or practical reasons) recognition of other civil rights such as individual expression and publication, or to various political rights. ${ }^{30}$

My final concern in this section is to ask about the second of Kang's approaches to justifying a central role for Confucianism in today's China, which revolves around the notion of culture. We will see in subsequent sections that those who believe Confucianism should play a role in the interpretation of human rights norms often tie their positions, in one way or another, to an idea of culture. Kang is notable for doing so in three different ways, though he is not always careful to distinguish them. The first approach is one of the most common: Kang argues that cultural continuity is vital to the continued existence of the Chinese. He says, in fact, that the Chinese people can survive the loss of their state, but even if their state were to persist, they could not survive the loss of their culture (ibid., xlvii). ${ }^{31}$ In another essay, he invokes the persistence over many centuries of Jewish cultural nationalism to support his point that a state is less important to a people than a culture (ibid., 181). If this is right, and if one is committed to the continuity of the Chinese people, and if Chinese culture can be substantially identified with Confucianism, then Chinese people should indeed seek to view contemporary political values through Confucian lenses. Let us call this the Continuity Argument. Unfortunately for Kang, his Continuity Argument is based on several mistaken premises. Let us grant that culture is one of the key marks of a people. But neither culture nor people are ever static configurations. Perhaps it is true that in the absence of a homeland, greater weight may fall on textual and interpretive continuity, though the many differences among the various American Jewish

\footnotetext{
${ }^{29}$ Contrast Analects 2:21, with 8:9. On the contrast between "individual (ren)" and "masses (min)," see Hall \& Ames 1987, 139-46.

${ }^{30}$ Henry Shue and others have argued for the interdependence of many "basic" rights. See Shue 1996.

${ }^{31}$ In a new essay titled "Outline of Confucian Constitutionalism (Rujia xianzheng lungang)," Kang makes the related argument that a constitution expresses the highest values of a "nation (minzu)," and the continuity needed for a "nation" to exist depends centrally on the nation's culture. Therefore, the national culture (which he says is primarily Confucianism in the Chinese case) must be the main source of the constitution. See Kang 2011.
} 
movements would seem to call even that into question. Another problem for Kang is the virtual identification of Chinese culture and Confucianism. This is problematic both because of the many other philosophical and religious movements that have contributed so greatly to Chinese culture, and because there is an enormous difference between the elite textual tradition that he calls Confucianism, and the plethora of ways in which loosely "Confucian" values came to be realized and practiced throughout Chinese society.

An adjunct to the Continuity Argument could be labeled the Competitive Argument: this is the view that we live in a world of global competition among civilizations, and Chinese should embrace cultural nationalism just as other peoples have. Successful cultural competition makes a nation, and its people, stronger. Individuals can shift from one culture to another, says Kang, and emigrants can be seen as cultural colonizers (ibid., 178). Kang puts a political and competitive spin on the idea of "cultural China" that Tu Weiming has sought to popularize for quite different reasons (on which see below): Kang sees it as part of a nationalist competition that transcends borders. The Competitive Argument clearly rests on two major premises. First, we should (or have no choice but to-although in this case the argument may collapse into the Continuity Argument) engage in inter-civilizational competition. Second, promoting Chinese culture means promoting Confucianism. This second premise has many of the same problems as the "Chinese culture equals Confucianism" premise in the Continuity Argument, though because we are now talking about forward-looking competition, I suppose that if Confucian values were particularly convincing to foreign and domestic audiences, that would provide reason to embrace them to even greater extents than had traditionally been the case.

Kang's final approach is the Unity Argument: it is culture, rather than economics, military force, politics, or ideology, that will hold China together despite the many centrifugal forces at work (ibid., 182). Perhaps the biggest problem with this argument is that Kang's approach to promoting Confucianism in China-which involves mandatory study throughout the educational system and its installation as China's "national religion"--looks much more like the imposition of an ideological system than like the natural flowering of existing elements of Chinese culture. As such, one wonders what success it would have in promoting unity, especially in outlying regions of the Chinese state. ${ }^{32}$

In sum, Kang Xiaoguang offers his readers a range of reasons to embrace what he calls a Confucian approach to politics, including limited roles for democracy and certain human rights, but not others. I have argued that the appearance of a literalist justification is largely misleading, and masks more indirect arguments that are

\footnotetext{
${ }^{32}$ Daniel Bell wonders whether Kang's Unity Argument can be salvaged by adding the qualification that Confucianism not be promoted as state religion in areas dominated by non-Han groups, like Tibet and Xinjiang [Personal communication]. Certainly some of the centrifugal forces about which Kang is worried are non-ethnic, and thus such a narrowed focus might still serve a useful unifying role. But it is far from obvious that Han Chinese in central areas of China will perceive the institution of a national Confucian religion as anything but a coercive, external imposition.
} 
accessible, if not necessarily convincing, whether or not one is committed to Confucianism.

\subsection{JIANG QING}

In 2003, Jiang Qing (1953- ) published Political Confucianism: The Changing Direction, Particularities, and Development of Contemporary Confucianism. Coupled with his efforts to revive traditional Confucian educational practices by founding an academy, Jiang has garnered considerable attention as a public intellectual. In this section, I concentrate on two aspects of Jiang's book: first, the kinds of relations he sees between Confucianism and Western philosophical traditions; and second, the ways he argues for his various conclusions. That is, I put his methodology and implicit justifications into the foreground.

Let us begin with what Jiang says is the justificatory method grounding political Confucianism, namely the study of Classics (jing-xue). For a variety of reasons, jingxue was abandoned in the twentieth century. Jiang's analysis here is quite astute, including such reasons as the transformation of jing-xue into pure historical scholarship and the doubting of antiquity; the role of Western disciplinary divisions in undermining the unity of the Classics - and with the loss of unity, so too a loss of sacredness; and the superficial exploitation of Classics by warlords (ibid., 155-7). As a result, Jiang concludes, any Chinese cultural revival lacks a foundation, since Chinese culture is expressed through the Classics, rather than being floating, unattached ideas. He writes: "the Classics are Chinese culture; depart from the Classics and it's [simply] not Chinese culture" (ibid., 157). Furthermore, he asserts that "study (xue)" of the Classics does not encompass any arbitrarily chosen approach to their appreciation or interpretation, but must be grounded in one of a small number of specific, systematic approaches. Interpretive traditions have schools, he says; one cannot undertake an interpretation of the Classics without a school to serve as context and guide. Without a school, one only has miscellaneous, random opinions that are little better than slogans (ibid., 161). Jiang then proceeds to summarize how one reads various Classics through the lens of his favored school. ${ }^{33}$ In the end, he concludes, "If Chinese culture cannot instantiate its Chinese characteristics, but completely embraces and accepts Western culture, then Chinese culture has become identical with Western culture, losing its self-identity, and losing its essence while superficially preserving its name" (ibid., 201).

I find all this both fascinating and deeply problematic. Part of its fascination lies in the ways it appears to parallel the hermeneutic approach of someone like AnNa'im. As we have seen above, according to such thinkers the only arguments acceptable in their communities are those grounded in their canon, as arrived at through the mechanism of legitimized interpretive techniques. However, whether or not one accepts this claim with respect to Muslims worldwide, I feel confident in

\footnotetext{
${ }^{33}$ Jiang bases his readings on the Gongyang hermeneutical tradition; for some relevant background on Gongyang Confucianism, see Elman 1990 and Wood 1995.
} 
asserting that Jiang Qing is mistaken with respect to China and Chinese communities. $\mathrm{He}$ is correct that the Chinese Classics have lost their sacredness, but this has farreaching implications that he has little power to combat. That a given idea or institution is recorded in one of the Classics is not, on its own, generally seen as a reason for people today to endorse it. Moreover, as we today seek to engage with these texts - which do, after all, contain a great deal of insight and are well worth our attention-we need not be constrained by one or another of the traditional schools of interpretation. We should realize that Jiang's conclusion-namely, Chinese culture must either "instantiate its Chinese characteristics" or else "completely embrace" Western culture - is a false dichotomy, at least if we take "Chinese characteristics" to mean the necessity of a grounding in jing-xue, as Jiang asserts.

One caveat to the strong claims I have just made is needed. In saying that Jiang has "little" power to combat the Classics' loss of sacredness, I acknowledge that he does retain some power: namely, he might be able to convince enough people to "reenchant" the Classics that they would come to have a new kind of authority. And indeed, Jiang is one among a number of contemporary Chinese from various walks of life who are endeavoring to manufacture a version of contemporary Confucianism that shares much in common with monotheistic religions like Christianity or Islam. In putting his goal this way, I am dramatically simplifying issues that Jiang treats with considerable subtlety; among other things, he emphasizes both the similarities and the differences between Confucianism and the Western category of "religion" (Jiang 2002). At the same time, he also partly downplays the significance of the fundamental social and institutional changes China has undergone in the last century, focusing instead on the intellectual movements calling for "enlightenment," which he deems to have been mistakes. In any event, a full treatment of the possibilities for Confucian religiosity is clearly outside the scope of the present essay. Suffice it to say that for now, and notwithstanding various evidence of novel Confucian religious practices in contemporary China, ${ }^{34}$ I find it unlikely that the Confucian Classics will ever have the kind of authority that Jiang hopes to find there.

I have already discussed above a variety of culture-based arguments for reading political philosophy through the lens of Confucianism. Several of Kang Xiaoguang's arguments draw implicitly or explicitly on ideas of Jiang Qing, though Kang tends to develop the arguments at more length), so I do not think there is much purpose in rehashing my critique of culture-based arguments here. Instead let me show that the strongest argument against the necessity of Jiang's hermeneutic methodology is made again and again elsewhere in his own book, albeit implicitly. Jiang undertakes sustained, critical engagement with books like Deng Zhenglai and Jing Yuejin's Constructing a Chinese Civil Society (Deng \& Jing 1992). In each such case, Jiang's argumentation is a model of what I am calling global philosophy. Nowhere does he rest an argument on the simple assertion of the various passages his jing-xue method highlighted. Let me give a brief example. Jiang nicely summarizes the view expressed by Deng Zhenglai and Jing Yuejin: a plurality of interest groups, of which the state is

${ }^{34}$ See, e.g., Billioud and Thoraval 2008. 
just one, will limit the ability of any power-holder. Jiang identifies two flaws, though: he argues that value pluralism will lead to a problematic form of value relativism, and also that losing the distinction between public and private power can lead to anarchism, and thus back to tyranny (ibid., 311-12). Furthermore, while Confucianism is not in conflict with pluralism, it also has "da-yi-tong" (great unity) which provides a common metaphysical basis. To be sure, in order to explain this idea of da-yi-tong, Jiang adverts to the Classics, among other sources. My point, though, is that his argument rests on reasons like the superiority of a metaphysical view that combines pluralism with an underlying value unity, rather than on any bald appeal to the Classics.

Jiang comes close to explicitly considering - and rejecting - the idea of rooted global philosophy (that I introduced in the first section, above) in a section of his book titled "Opinions on 'Global Ethics' from the standpoint of Chinese Confucianism." Jiang's main stalking horse is the Universal Declaration Toward a Global Ethic that was promulgated in 1993 by the Parliament of World Religions under the leadership of Hans Kung. ${ }^{35}$ As Jiang understands the Declaration's goals, it aims to articulate a single, global ethic that can become a basis for solving shared human problems like poverty, war, ecological destruction, and so on (ibid., 341). Jiang's response is that the world is not ready for such a utopian possibility. Rejecting the optimism and belief in progress he sees in enlightenment thinkers, humanists, economic determinists, worshippers of democracy, and advocates of human rights, Jiang asserts that we are not in the best era of human history, but rather in the most chaotic. He invokes a Confucian theory of three successive eras and says that we are a long distance from the "Era of Great Peace," in which (alone) would global ethics be possible. Instead, we must look to solve our problems, whatever their scope, by appeal to our local, tradition-based moralities. Ethics is rooted in historical particularities, he argues; modern communications and so-called globalization have not fundamentally changed this. A "global ethic," therefore, would have to be "abstract" or "transcendent": in either case, actual, particular nationalities will feel no affinity for the global ethic (ibid., 343).

While there are aspects of Jiang's argument that I would criticize, ${ }^{36}$ the main point to make here is that "global ethics" is fundamentally different in method and aspiration from rooted global philosophy. Given that he engages successfully in the latter, as I have shown, I hope that Jiang would be comfortable endorsing its modest goals. I also want to acknowledge that some of Jiang's worries about miscellaneous,

\footnotetext{
${ }^{35}$ See http://www.weltethos.org/dat_eng/index3 e.htm, accessed 20 November 2008.

${ }^{36}$ For one, there is good reason to think that the broadening of our moral vision seen in movements like human rights and environmentalism reflect progress, even if it has been uneven and coexists with some of history's worst atrocities. For another, the monolithic notion of a "nationality" finding affinity in an ethic is too crude and fails to reflect stresses and opportunities for change within nations or traditions. Finally, Jiang goes on to argue for a static picture of cultural systems and their attendant moralities, maintaining first that we cannot create new moralities, and second that if we only revived and adhered to our traditions, all would be well. This seems simply blind to myriad changes in culture, morality, and circumstance that peoples of all times and places have experienced. See ibid., 343-5.
} 
random interpretations of the Classics, mentioned above, might have some substance, even if the answer to these worries is not what Jiang thinks it is. There is an inevitable tension between historical fidelity and philosophical construction. The former pushes us toward carefully qualified, highly context-sensitive interpretations; the latter, toward generalization, loose paraphrase, critical emendation, and more. No matter what our goals, anyone dealing with an intellectual tradition finds him or herself pulled back and forth between these poles. No one is a pure "historian" or pure "philosopher." Historians cannot do their work without endeavoring to genuinely understand (and thereby become engaged by) the ideas with which their subject grappled. For their part, philosophers cannot make words they have inherited from a tradition mean whatever they want: changing things requires work, the work of engaging with the tradition's meanings, to one degree or another. Unless one does this, one risks making the tradition into a set of random slogans, just as Jiang warns. Our conclusion should not be to confine ourselves in all cases to tradition-sanctioned hermeneutics, however; as Jiang's own work shows, in the case of contemporary Confucianism, elaborate hermeneutics are distracting rather than constructive.

\subsection{TU WEI-MING AND CREATIVE TRANSFORMATION}

Scholar, philosopher, and public intellectual, Tu Wei-ming (1940- ) is probably the leading voice for Confucianism in the contemporary world. Tu was until recently Director of the Harvard-Yenching Institute, which both put him at the center of USChina educational exchange, and gave him the freedom to lecture widely on Confucianism and on global dialogue in ethics and religion. I will use $\mathrm{Tu}$, as well as a representative younger scholar, to present a rather different perspective on Confucianism and human rights from that of either Kang or Jiang. Tu calls for the "creative transformation" of the Confucian tradition in dialogue with many other traditions. He adopts an affirmative stance toward Confucianism, to be sure, but argues for a new era in Confucianism that fully digests and learns from both history and alternative traditions. He is thus both an heir of the "New Confucians" of the middle decades of the twentieth century, and a leader in a movement to go even further than they in remaking Confucianism. ${ }^{37}$ At the same time, he is also a passionate advocate of the importance of adherents of other traditions-and in particular, the liberal West-learning from Confucianism. As we will see, the articulation and defense of human rights are not, in Tu's eyes, settled issues, but evolving processes.

I begin with Tu's perspective on why anyone should care about Confucianism. He does not put forward a facile equation of Chinese culture with Confucianism, though he is impressed with the degree to which asking about connections between Confucianism and distinctive features of East Asian modernization seems to lead to productive answers. He is cautious about these connections, and acknowledges that a strong thesis regarding the role of clearly-identified Confucian ethics or practices in

${ }^{37}$ On New Confucianism, see Bresciani 2001 and Makeham 2003. 
contemporary East Asia "has yet to be substantiated" (Tu 1996a, 3). ${ }^{38}$ Still, one reason for caring about the relations between Confucianism and human rights is to see if it can shed light on how values like human rights might best be realized in East Asia. More fundamentally, I would say that Tu's deepest reason for caring about the relationship is that he identifies himself as a Confucian, and sees Confucianism as a broadly attractive, broadly relevant philosophical and spiritual movement. Tu articulated the idea of "cultural China" in part to recognize the phenomenon of people outside China - and not just people whose ancestors came from China-who value and participate in aspects of Chinese culture and traditions (Tu 1991). Unlike Kang Xiaoguang's appropriation of "cultural China" as cultural colonization in a competition among civilizations, Tu views the idea principally in a spiritual and philosophical context.

I said that $\mathrm{Tu}$ "identifies himself as a Confucian." Is this the same as saying that he believes in Confucianism? Recall from above my discussion of Kang Xiaoguang's references to the common people in Imperial times as "believers (xin-tu)." There I noted that even in the context of Kang's quite idiosyncratic discussion, the focus is on behavior and on sincere commitment to ideals; indeed, "sincere adherents" might be a better translation of $x i n-t u$ than the more conventional "believers." A similar logic applies to the current question. Tu Wei-ming is certainly a follower of the Confucian Way, as best he is able, but there is no transcendent source of Confucian truth-no revelation, no scripture - in which it would be appropriate to say he "believes" (or has "faith"). Like Confucians throughout the ages, he has the greatest respect for the wise and influential practitioners who have preceded him: both for their personal examples, as well as for their recorded interpretations of the Way. But the lack of a strict canon opens up the process of "creative transformation" in ways harder to imagine for sincere Muslims.

It is well known that Chinese traditions of spiritual practice typically do not demand exclusive commitment on the parts of their practitioners. This attitude is reinforced by the widespread view that while there is but a single "way," different traditions can all capture or manifest aspects of that way. The acme of such a pluralistic orientation to spiritual traditions comes in explicit movements claiming that the "Three Teachings are One (san-jiao-he-yi)," but it is also found in the thought and practice of countless individuals who did not subscribe to such an explicit claim. In any event, it is helpful to remember such pluralistic practices from "traditional" Confucians when we reflect on Tu's call for the creative transformation of Confucianism in dialogue with all of the world's traditions.

At the center of Tu's enterprise is what he calls a "spiritual joint venture for human co-existence and mutual flourishing" (1996b, 10). According to Tu, this is grounded on the core Confucian teaching that "In order to establish ourselves, we must help others to establish themselves; in order to enlarge ourselves, we must help

\footnotetext{
${ }^{38}$ For incisive criticism of such a strong thesis, see Dirlik 1995.
} 
others to enlarge themselves." 39 The Confucian vision of human relatedness thus leads directly to openness and dialogue:

An inclusive sense of community based on the communal critical self-consciousness of the reflective minds is an ethico-religious goal as well as a philosophical ideal. The mobilization of three kinds of spiritual resources is necessary to ensure that this simple vision be grounded in the historicity of the cultural complexes informing our way of life today. $(1996 b, 12)$

The three types of spiritual resources on which we must draw are (1) the traditions of the modern West; (2) those derived from non-Western historical civilizations; and (3) primal or indigenous traditions. Each type has important contributions to make toward what Tu calls a "new synthesis" (ibid., 14).

A central part of the "communal critical self-awareness" that we must collectively bring to the dialogue Tu envisions is disciplined reflection on our traditions, including "the feminist critique of tradition" (1996b, 18). By way of fleshing out what the creative transformation of Confucianism might look like, I want to examine a specific critique of Confucianism that is informed, in part, by a commitment to broad ideals of human rights and equality. In "Gender and Relationship Roles in the Analects and the Mencius," philosopher Sin Yee Chan argues that one can and should discard the conception of gender that is implicit in classical Confucianism, along with the subordination of women we also find in these texts, "without relinquishing one's commitment to the core doctrines of early Confucianism" (Chan 2000, 115). Chan's argument is an example of internal criticism, in that she draws on the Confucian texts themselves to expose inconsistencies in those texts' positions, and critiques certain values the texts espouse based on more central values from the same texts. In the background, to be sure, are her commitments to women's rights and feminism, but the specific ways in which these ideals are articulated are distinctively Confucian.

Chan's strategy is to expose the degree to which classical Confucian texts imply that women should be subordinated to men; then to argue that there is no good grounding in the texts for these forms of exclusion and subordination; and finally to argue that a Confucianism re-cast along equitable gender lines would still respect key Confucian commitments, even including functional role distinctions and the five relationships, though role distinctions will no longer map directly onto sex differences and the "husband - wife" relationship will need to be reconfigured (ibid., 127). Chan's argument is powerful and convincing. Suggestions that women be excluded from political participation, from education, and from striving for moral ideals (like sagehood) are inconsistent with central aspects of Confucianism, such as its recognition of a continuity between family/social and political spheres. Creative transformation of Confucianism, in short, means re-thinking what Confucianism really teaches in the light of what we know now about ways that patriarchy, prejudice, and discrimination have been exposed in other cultures and traditions. It is worth

${ }^{39}$ Ibid.; Analects 6:28. 
noting that important parts of Chan's argument were anticipated by Confucian critics of their tradition's patriarchy well before the advent of modern feminism, which further enhances the status of her argument as "internal criticism."

In light of An-Na'im's elaborate hermeneutics, which enable him to abrogate certain problematic passages in favor of more universal and egalitarian verses, it is striking that Chan often feels no need to engage in such interpretive gymnastics. One of the passages she cites to explicate the classical Confucian conception of gender is Mencius's endorsement of the following statement from The Book of Odes: "He set an example for his consort, and also for his brother, and so ruled over the family and the state." ${ }^{41}$ Chan points out the way in which this allows men to dominate the family, even though their paradigmatic functional role is supposed to be "outside" the home. Another problematic passage is Mencius's endorsement of the following, from The Book of Rites: "A prince ploughs himself, and is assisted [by the people] to supply millet for sacrifice. His wife keeps silkworms and unwinds their cocoons, to make garments for sacrifice." 42 As Chan says, a gendered, functional distinction is assumed throughout the texts, and made explicit here. Rather than try to re-interpret such passages, Chan simply criticizes the theory they express, and then sets them aside. This is not to say that she cannot think of a way to try to explain them away: rather, in the spirit of transformation, she does not feel the need to do so. ${ }^{43}$

It should be clear from my account that while Chan's Confucianism is supportive of women's human rights in a way that classical Confucianism was not, she is still presenting a Confucian view, based on distinctively Confucian values and justified in part by the commitments expressed in Confucian texts. Like $\mathrm{Tu}$, she believes this orientation is attractive and available to open-minded individuals from around the world, and so her position rests as much on the persuasiveness of the Confucian world-view as it does on the mere fact that certain values are endorsed in the Analects or Mencius. This points to an important aspect both of Tu's project, and to that of many other contemporary thinkers who write about the relationship between Confucianism and human rights norms. These thinkers are not just interested in the creative transformation of Confucianism, but also in corresponding developments in the other moral languages in which human rights might be discussed. This is often put in terms of the need to learn from Confucianism. Here, for instance, is Roger Ames: "We should welcome the debate with China as an opportunity to critically examine our own notions of human rights," and furthermore, "if [as I have argued] the American democracy will be changed in any sustained relationship with China, an

\footnotetext{
${ }^{40}$ See Jin 2004, in which the author shows that seventeenth-century Confucian Tang Zhen argued for mutuality and reciprocity being at the center of the husband-wife relationship, and recognizes the moral necessity of women participating in wider society.

${ }^{41}$ Chan 2000, 118, citing Mencius 1A:7.

${ }^{42}$ Chan 2000, 118, citing Mencius 3B:3.

${ }^{43}$ Occasionally Chan does interpret away seemingly misogynist passages - see her discussion of the Analects' infamous "It is hard to take care of the women and the petty men" (17:25) at ibid., 126 but she only does so to make a particular point, not because of a felt need to render the entire text acceptable.
} 
understanding and critical appreciation of the Chinese experience might make it a change for the better" (Ames 1997, 178 and 181).

It can sometimes be unclear what the ultimate goal is for philosophers who emphasize creative transformation and dialogue. Tu Wei-ming, in particular, is somewhat ambiguous on this score. For instance, after an elegant and insightful reflection on the Confucian "five virtues," he writes: "These are not simply Confucian issues; these are issues that we need to address as reflective modern persons, if we are serious in transforming "human rights" into a universal language of humanity" (1996b, 25). This sounds like his goal is a single, universal language for all humanity, as do his references earlier to a "new synthesis" and the "cultivation of a global ethic" (ibid., 19). On the other hand, he concludes by stressing the critical question of:

...how East Asian intellectuals can be enriched and empowered by their own cultural roots in their critical response to already partially domesticated Enlightenment heritage. The full development of human rights requires their ability to creatively transform the enlightenment mentality of the modern West into a thoroughly digested cultural tradition of their own; this, in turn, is predicated on their capacity to creatively mobilize indigenous social capital and cultural assets for the task. (ibid., 29)

This sounds less like a single language than a distinctive, local response to dialogue among various traditions.

There is nothing about the creative transformation approach that necessitates or assumes the possibility of a single, universal moral language or ethic. It is essentially a version of rooted global philosophy, in the sense I described above. Given that one aspect of the approach is to reflect on our traditions in light of what we see in, or learn from, others' traditions and experiences, then it should not be surprising if our various traditions resemble one another more at the end of such reflection than at the beginning. It is possible that the result will be what Charles Taylor has described as an "unforced consensus" on broad human rights norms, though allowing for differences in various details and in the underlying justifications for the broad values (Taylor 1999). It may well be that Tu envisions just such a process, which accounts for his sliding between more- and less-universalistic language. No matter whether an eventual consensus emerges or not, "creative transformation" itself will continue to balance a rootedness in distinctive traditions with argumentation that is typically quite broadly accessible.

\subsection{INSTRUMENTALISM}

So far we have looked at three Confucian approaches to human rights, rough correlates to the Islamic views I labeled literalist, hermeneutic, and transformative. Particularly with respect to the first two of these, we have seen ways in which the epistemological underpinnings of Kang's and Jiang's Confucian views differ substantially from the Islamic views of Mawdudi and An-Na'im, respectively. Before 
moving to the essay's concluding section, I want to consider a final Confucian approach, which I label instrumental. For reasons I will discuss, the instrumental approach seems to be less prominent in Islamic discussions of human rights.

In order to illustrate the instrumental approach, I will draw primarily on Daniel A. Bell's East Meets West: Human Rights and Democracy in East Asia. Bell is not solely concerned with Confucianism, nor are his arguments solely instrumentalist. He gives us a particularly clear and detailed sense of what I mean by instrumentalist, though, as well as helping us to see how instrumentalist approaches can blend with some of the other epistemologies of Confucian human rights that I have already discussed.

The core idea of an instrumentalist approach to Confucianism is that human rights advocates should take Confucian ideas and institutions seriously because that will make the adoption of human rights norms easier, more rapid, and more lasting. As Bell says, "If the ultimate aim of human rights diplomacy is to persuade others of the value of human rights, then in my view the struggle is more likely to be won if it is fought in ways that build on, rather than challenge, local cultural traditions." 44 Let me emphasize that one need not view such arguments as merely instrumental (or strategic): one might also identify with the local cultural tradition in question, or else view the respect we owe to this local tradition as requiring that we try to "build on" instead of "challenge." I set these matters aside, though, because my concern here is with the distinctive motivation that all instrumentalist arguments share.

Bell elaborates a variety of ways in which an instrumentalist approach might be pursued. For starters, finding a way to put human rights norms into local language to domesticate or indigenize them - may help to keep the norms and their advocates from seeming like expressions of cultural imperialism. Putting some distance between the norms and their mode of expression in the U.S. may also help to calm the fears of those who are worried that human rights automatically mean excessive legalism, rampant individualism, collapsing families, and other social ills that many in East Asia associate with the U.S. (Bell 2000, 57). Another idea that Bell considers is using justifications that are based in the local tradition's norms; indeed, as Bell says, "cultural traditions can shed light not only on the most effective arguments for human rights, but also on the groups most likely to bring about human rights reforms." In Confucian-influenced cultures, he says, intellectuals play a very important public role (ibid., 71-3). Finally, Bell suggests that tradition-based non-legalistic mechanisms may sometimes do a superior job of realizing and/or protecting human rights norms (ibid., 76).

I believe Bell's arguments are cogent, and provide reasons to take local cultures seriously - in a limited but important way-in discussions and advocacy of human rights and democracy. When we think specifically about the relevance of this style of argument to Confucianism, however, two caveats are needed. First, we must be

\footnotetext{
${ }^{44}$ Bell 2000, 55. I attribute this statement to Bell, but in fact it is made by one of the characters Bell created, Joseph Lo; the whole of East Meets West is cast as a dialogue among several pairs of interlocutors. In context, it seems to be a statement that Bell himself would endorse.
} 
careful to guard against any essentialisation of the culture of China (or Hong Kong, or Singapore, etc.) that makes it into a static, monolithic entity largely congruent with classical Confucianism. Knowledge of the Analects is not equivalent to "local knowledge" of contemporary China or Hong Kong. Bell, who has lived in Hong Kong and Singapore and who as of this writing resides in Beijing, is keenly aware of this concern, and in fact his examples of local knowledge are subtle and wellgrounded in the complex reality of these communities. This is of course not to say that the Analects is irrelevant to contemporary China; it matters so long as contemporary Chinese take it to matter, and many do. A second caveat arises out of a challenge that Bell puts into the mouth of one of the fictional parties to his dialogue. Sam Demo says to the equally fictional Professor Wang, "But you seem to be drawing only on the 'liberal' parts of the Confucian tradition, leaving out the rest. Unfortunately, actually existing Confucianism tended to draw more on the part that supported the authoritarian, hierarchical status quo" (ibid., 300). Wang's response is to emphasize the ways in which "far from justifying blind adherence to the political status quo, Confucian values often provided intellectual resources for social critics" (ibid., 302-3). This is true, and helps to answer Demo's challenge, but it is less responsive to the question I see raised here, namely: isn't a Confucian also beholden to the less-liberal parts of the tradition? Wang's-and Bell's, and instrumentalism's - implicit answer is that he is content to discard problematic material. Like a proponent of Tu's transformation, for an instrumentalist there is no canon. $^{45}$

One final point. I have just suggested that at least as deployed in Confucian contexts, the instrumental and transformative approaches resemble one another in their lack of commitment to a strict canon. Another relation between the two approaches is that insofar as an attempt to be sensitive to local conditions begins to suggest that the ultimate goals of one society might be different from those of another, we have moved from the sphere of instrumentalism to that of broader dialogue and transformation. If one is doing more than putting Confucian clothes on universal human rights, but is seeing ways in which someone sensitive to Confucian values might want to articulate the underlying human rights values differently, this is no longer mere instrumentalism. Bell's fictional dialogues are ultimately rather inconclusive on whether revision of end-goal is appropriate and justified, perhaps because this is a question for actual communities to decide for themselves (ibid., 110).

\section{SYNTHESIS AND CONCLUSION}

Literalist, hermeneutic, creative transformation, instrumentalist: the goal of this essay has been to show that these approaches seem to be adopted by both contemporary

\footnotetext{
${ }^{45}$ Even an instrumentalist would be faced with a challenge if it could be shown that somehow the liberal parts and the less-liberal parts logically entailed one another. For an effort to make out such an argument, see Ci 1999.
} 
Islamic and Confucian intellectuals, but also to argue that there are critical differences in the ways the various approaches are developed. Kang Xiaoguang seems to be a literalist like Sayyid Mawdudi, and comes to some similarly odd conclusions about democracy and human rights on this basis. It is hard to agree with Mawdudi that he is talking about human rights at all, whatever one makes of the values he is endorsing. Kang, however, is something of a schizophrenic. His literalist conclusions (about justified political transitions, for instance) and his advocacy of a Confucian religion are quixotic, but he also recognizes shortcomings in Confucianism. When he argues in this latter mode, seeing value in Confucianism but also genuinely engaging with values and institutional solutions from outside the tradition, he can be quite insightful and provocative, whether or not we are ultimately persuaded. This reasoning, though, is not literalist or in another way dependent on the tradition, but instead is global philosophical reasoning which he expects to be accessible to any of us.

Both An-Na'im and Jiang Qing advocate complex, tradition-based hermeneutics. Both see reliance on such hermeneutics as essential for developing a robust, contemporary version of their respective traditions. As we have seen, though, the similarities end there. Jiang Qing fails to adequately justify or persuasively employ his hermeneutic methods; when he does put forward incisive arguments, they are in the same global philosophical mode that we saw from Kang Xiaoguang. An-Na'im, on the other hand, does seem to rely on his hermeneutic framework, even if there may be some questions as to how we know for sure that problematic verses of the Qur'an all date from the Medinan period.

None of my categories is rigorously defined, and one can sometimes blend into another. This may be particularly true of "creative transformation," which after all does rely on interpretation of the tradition's key texts. The individuals I examined under this rubric are perhaps the closest to having genuine similarities. Tu Wei-ming is committed to Confucianism, and to the value of Confucius's vision for human civilization, in something like the way that Mernissi views Islam and Mohammed. Both also see a transformation of their respective traditions on the issue of women's rights as required. Mernissi's method, of setting certain tenets of the tradition up against others, can even be compared to Chan's style of argument. One significant area of difference, though, may be a different comfort level with simply abandoning canonical sayings that fit poorly with genuinely recognizing the equality of women. Mernissi can clearly tolerate this for hadith, but what can she make of problematic verses from the Qur'an itself?

I have not offered an explicit example of an instrumentalist approach to Islam and human rights, though instrumental concerns are certainly in the mind of An-Na'im, at least. Some of his critics suggest we should abandon his complex hermeneutics and simply argue for human rights on secular grounds (Ahmed 1993). An-Na'im replies that secularism lay at the core of the failed modernist movements throughout the Muslim world in the nineteenth and twentieth centuries. To resort to purely secular argument is tantamount to admitting that believing Muslims should heed only what the clerics say: "By conceding religious authority to the proponents of shari'a, secularist intellectuals are conceding defeat without a fight" (An-Na'im 1990, 62). 
The upshot of this instrumental justification, of course, is much more restrictive than those we saw put forward by Bell, who is still content to allow considerable looseness in what one picks and chooses from Confucian texts and actual Chinese culture in order to respect local conditions.

One conclusion that we can come to from all this is that Kang Xiaoguang and Jiang Qing notwithstanding, Confucians today have a very different relation to their textual tradition than do Muslims. In earlier centuries when Confucians could more properly be described as having a canon of "classics (jing)," I would argue that there were still differences between the various attitudes one finds toward these classics, on the one hand, and the variety of Muslim attitudes toward revelation, in particular. This is a complex topic, though, and I will not pursue it here. My focus has been on the contemporary moment. Texts are still very important to Confucians and to those attracted to Confucianism. ${ }^{46}$ The Confucian textual tradition simply does not constrain people today in the same way that the Muslim canon does, however. Of the three Muslim approaches we examined, the two that take human rights seriously are both highly controversial. From the standpoint of justification, in short, Confucian advocates of human rights seem to be on much firmer ground than their Islamic counterparts.

A final topic to consider is the role that culture plays in several of the Confucian arguments. In the minds of Kang and Jiang, at least, it sometimes appears that culture plays a fundamental, conversation-ending role similar to that played by revelation in the Islamic context. The role an outsider can play with respect to these different foundational commitments, though, is quite different. I may not believe that God revealed anything to Mohammed, but the concept of revelation itself seems coherent; there is little I can say to a believer about the status of revelation, except perhaps to remind him or her that as soon as human minds become involved, there is necessarily an aspect of interpretation involved in any articulation of revelation. The ideas of "culture" employed by Kang and Jiang - among others - in contrast are much more susceptible to outside critique. As I suggested above, several of their formulations rely on essentialist, monolithic ideas of culture that are simply not tenable, given what we now understand about the ways in which people, practices, and norms interact and change. The upshot is that there is even more reason to expect Confucians to be full, open participants in diverse global discussions about human rights.

\section{ACKNOWLEDGEMENTS}

I owe many thanks to the four anonymous reviewers who read this essay and offered helpful criticisms and suggestions. I believe the essay is considerably stronger as a result of their input. Thanks, too, to Daniel Bell, who read and commented extensively on an earlier version. I am also in the debt of several years' of students in

\footnotetext{
${ }^{46}$ See, for instance, the discussion of textual tradition via-a-vis Confucianism as "portable tradition" in Neville 2000.
} 
my "Human Rights Across Cultures" class, who always find ways to challenge me and further refine my thinking on matters related to the concerns of this essay. Finally, I want to express my appreciation to Bo Mou, whose efforts on behalf of the pluralistic pursuit of global, comparative philosophy have been so substantial.

\section{REFERENCES}

Ahmed, Ishtiaq (1993), Abdullahi An-Na'im on Constitutional and Human Rights Issues. In Lidholm, T., \& Vogt, K. (Eds.), Islamic Law Reform and Human Rights: Challenges and Rejoinders (Copenhagen: Nordic Human Rights Publications).

'Ali, 'Abdullah Yusuf (trans.) (1999), The Meaning of the Holy Qur'an (Beltsville, Maryland: Amana Publications).

Ames, Roger T. (1997), Continuing the Conversation on Chinese Human Rights. Ethics \& International Affairs, 11: 177-205.

Angle, Stephen C. (2002), Human Rights and Chinese Thought: A Cross-Cultural Inquiry (New York: Cambridge University Press).

---- (2005a), "Decent Democratic Centralism”, Political Theory, 33 (4): 518-46.

---- (2005b), "Must We Choose Our Leaders? Human Rights and Political Participation in China", Journal of Global Ethics, 1(2): 177-96.

----(2012), Contemporary Confucian Political Philosophy: Toward Progressive Confucianism (Cambridge, UK: Polity Press).

An-Na'im, Abdullahi (1990), Toward An Islamic Revolution: Civil Liberties, Human Rights, and International Law (Syracuse, NY: Syracuse University Press).

---- (1993), "Toward an Islamic Reformation: Responses and Reflections", in Lidholm, T. \& Vogt, K. (eds.), Islamic Law Reform and Human Rights: Challenges and Rejoinders (Copenhagen: Nordic Human Rights Publications), 97-116.

---- (2000), "Human Rights and Islamic Identity in France and Uzbekistan: Mediation of the Local and Global", Human Rights Quarterly, 22: 906-41.

Arberry, A. J. (trans.) (1955). The Koran Interpreted (New York: Simon \& Schuster). Arkoun, Mohammed (1993), "The Concept of "Islamic Reformation", In Lidholm, T. \& Vogt, K. (eds.), Islamic Law Reform and Human Rights: Challenges and Rejoinders (Copenhagen: Nordic Human Rights Publications), 11-24.

Bakar, Osman \& Cheng, Gek Nai (1997), Islam and Confucianism: A Civilizational Dialogue (Kuala Lumpur: University of Malaya Press).

Bell, Daniel A. (2000), East Meets West: Human Rights and Democracy in East Asia (Princeton, NJ: Princeton University Press).

Benite, Zvi Ben-Dor (2005), The dao of Muhammad : a cultural history of Muslims in late imperial China (Cambridge, MA. ; London: Published by the Harvard University Asia Center : Distributed by Harvard University Press).

Berween, Mohamed (2003), "International Bills of Human Rights: An Islamic Critique", International Journal of Human Rights, 7 (4): 129-42. 
Billioud, Sébastien \& Thoraval, Joël (2008), “Anshen liming or the Religious Dimension of Confucianism", China Perspectives, 3: 88-106.

Bresciani, Umberto (2001), Reinventing Confucianism: The New Confucian Movement (Taipei: Ricci Institute for Chinese Studies).

Brown, Daniel (1996), Rethinking Tradition in Modern Islamic Thought (Cambridge: Cambridge University Press).

---- (1998), "The Triumph of Scripturalism: The Doctrine of Naskh and its Modern Critics", in Waugh, E. H., \& Denny, F. M. (eds.), The Shaping of an American Islamic Discourse: A Memorial to Fazlur Rahman (Atlanta: Scholar's Press), 4966.

Chan, Joseph (1999), “A Confucian Perspective on Human Rights for Contemporary China", in The East Asian Challenge for Human Rights (New York: Cambridge University Press), 212-40.

Chan, Sin Yee (2000), "Gender and Relationship Roles in the Analects and the Mencius", Asian Philosophy, 10 (2): 115-32.

Ci, Jiwei (1999), "Zheng-Dang-Shan-Yu-Quan-Li-Zai-Ru-Xue-De-Di-Wei [The Right, the Good, and the Place of Rights in Confucianism]", Guo-Ji-Ru-Xue-YanJiu, 6: 175-204.

Deng, Zhenglai \& Jing, Yuejing (1992), "Jian-Gou-Zhong-Guo-De-Shi-Min-She-Hui [Constructing a Chinese Civil Society]", Zhong-Guo-She-Hui-Ke-Xue-Ji-Kan, 1: 58-68.

Dirlik, Arif (1995), "Confucius in the Borderlands: Global Capitalism and the Reinvention of Confucianism", boundary, 2: 229-73.

Elman, Benjamin A. (1990), Classicism, Politics, and Kinship: The Ch'ang-Chou School of New Text Confucianism in Late Imperial China (Berkeley: University of California Press).

Hall, David L., \& Ames, Roger T. (1987), Thinking Through Confucius (Albany: State University of New York Press).

Jiang, Qing (2002), "Ren-Lei-She-Hui-De-Zui-Gao-Li-Xiang: Zhong-He-Zhi-MeiJiang-Qing-Xian-Sheng-Tan-Ru-Jia-De-Zong-Jiao-Xing-Wen-Ti [In Search of Humanity's Highest Ideal: Harmonious Enchantment-Jiang Qing on the Problem of Confucian Religiosity]", from http://www.confucius2000.com/ confucius/zqlrshdzglxzhzmjqtzj.htm; accessed 1 December 2011.

---- (2003), Zheng-Zhi-Ru-Xue: Dang-Dai-Ru-Xue-De-Zhuan-Xiang-Te-Zhi-Yu-FaZhan [Political Confucianism: The Changing Direction, Particularities, and Development of Contemporary Confucianism] [Beijing: San-Lian-Shu-Dian (Harvard-Yenching Academic Series)].

Jin, Dejun (2004), "Ru-Jia-De-Ren-Quan-Si-Xiang — Yi-Tang-Zhen-De-Nan-NüPing-Deng-Si-Xiang-Wei-Zhong-Xin [Confucian Human Rights Thought Focused on Tang Zhen's Doctrine of Gender Equality]”, in Chen, Q., \& Zhang, S. (eds.), Ru-Jia-Chuan-Tong-Yu-Ren-Quan / Min-Zhu-Si-Xiang [The Confucian Tradition and Human Rights / Democratic Thought] (Jinan: Qi-Lu-Shu-She). 
Kang, Xiaoguang (2005). Ren-Zheng: Zhong-Guo-Zheng-Zhi-Fa-Zhan-De-Di-SanTiao-Dao-Lu [Humane Governance: A Third Road for China's Political Development]. (Singapore: Global Publishing).

Kang, Xiaoguang (2011), "Ru-Jia-Xian-Zheng-Lun-Gang [An Outline of Confucian Constitutionalism]", Ru-Jia-You-Bao [Confucian Newsletter], n.p.

Kurzman, Charles (ed.) (1998), Liberal Islam: A Sourcebook (New York: Oxford University Press).

----(ed.) (2002), Modernist Islam: A Sourcebook (New York: Oxford University Press).

Makeham, John (2003), "The Retrospective Creation of New Confucianism", in Makeham, J. (ed.), New Confucianism: A Critical Examination (New York: Palgrave), 25-53

Mawdudi, Abul A'la (1960), The Islamic Law and Constitution (Lahore: Islamic Publications, Ltd).

---- (1980), Human Rights in Islam (Leicester: The Islamic Foundation).

Mayer, Ann Elizabeth (1993), “A Critique of An-Na'im's Assessment of Islamic Criminal Justice", in Lidholm, T. \& Vogt, K. (eds.), Islamic Law Reform and Human Rights: Challenges and Rejoinders (Copenhagen: Nordic Human Rights Publications), 37-52.

---- (1999), Islam and Human Rights (Boulder, Colorado: Westview Press).

Mernissi, Fatima (1991). The Veil and the Maile Elite: A Feminist Reinterpretation of Women's Rights in Islam. Reading, Massachusetts: Addison-Wesley.

---- (1992), Islam and Democracy (Cambridge, MA: Perseus Publishing).

Murata, Sachiko, Chittick, William C., Tu, Weiming \& Liu, Jielian (2009), The sage learning of Liu Zhi : Islamic thought in Confucian terms (Cambridge, Mass.: Published by the Harvard University Asia Center for the Harvard-Yenching Institute : Distributed by Harvard University Press).

Nasr, Seyyed Vali Reza (1996), Mawdudi and the Making of Islamic Revivalism (New York: Oxford University Press).

Neville, Robert Cummings (1994), "Confucianism as a World Philosophy: Presidential Address for the 8th International Conference on Chinese Philosophy, Beijing, 1993", Journal of Chinese Philosophy, 21: 5-25.

----(2000), Boston Confucianism: Portable Tradition in the Late-Modern World (Albany, New York: SUNY Press).

Othman, Norani (1999), "Grounding Human Rights Arguments in Non-Western Culture: Shari'a and the Citizenship Rights of Women in a Modern Islamic State", in The East Asian Challenge for Human Rights (New York: Cambridge University Press), 169-92.

Ownby, David. (2009), "Kang Xiaoguang: Social Science, Civil Society, and Confucian Religion", China Perspectives, 4: 101-11

Rahman, Fazlur (1982), Islam and Modernity: Transformation of an Intellectual Tradition (Chicago: University of Chicago Press).

Ramadan, Tariq (2001), Islam, the West, and the Challenges of Modernity (Markfield, Leicester: Islamic Foundation). 
----(2004), Western Muslims and the Future of Islam (Oxford: Oxford University Press).

Shue, Henry (1996). Basic Rights (Princeton: Princeton University Press).

Solomon, Robert C. (2001), “' 'What is Philosophy?' The Status of World Philosophy in the Profession", Philosophy East \& West, 51 (1): 100-3.

Tabandeh, Sultanblussein (1970), A Muslim Commentary on the Universal Declaration of Human Rights (Guilford, England: F. J. Goulding).

Taha, Mahmoud Mohamed (1987), The Second Message of Islam (Syracuse, NY: Syracuse University Press).

Taylor, Charles (1999), "Conditions of an Unforced Consensus on Human Rights", in Bauer, J. R., \& Bell, D. A. (eds.), The East Asian Challenge for Human Rights (New York: Cambridge University Press).

Tu, Wei-ming (1991), "Cultural China: The Periphery as the Center", Daedalus, 120 (2): $1-32$.

----(1996a), "Introduction", in Tu, Wei-ming (ed.), Confucian Traditions in East Asian Modernity (Cambridge: Harvard University Press), 1-10.

---- (1996b), A Confucian Perspective on Human Rights: The Inaugural Wu Teh Yao Memorial Lecture (Singapore).

Wadud, Amina (1999), Qur'an and woman : rereading the sacred text from a woman's perspective (New York ; Oxford: Oxford University Press).

Wood, Alan T. (1995), Limits to Autocracy: From Sung Neo-Confucianism to a Doctrine of Political Rights (Honolulu: University of Hawaii Press). 
